\title{
RECRUITMENT INDEX AND APPOINTMENT PROCEDURES FOR TENURE-LINE FACULTY AT ISLAMIC AZAD UNIVERSITY:
}

Faculty Vacancy Determination Index

(Az Index)

2008

Javad Aziziyan

Islamic Azad University, $6^{\text {th }}$ Region Chanceller $\underline{\mathrm{J}}$

azizian@yahoo.com

\begin{abstract}
Regarding the position and significance of the faculty members as one of the indisputable principles underlying any university and their function both in promoting the academic level and in developing knowledge scopes and borders, as well as regarding the contribution and the role the Islamic Azad University can make and play in provision of the academic requirements of the country, this university in its present status aims to recruit all its required faculty members in terms of its strategic and academic development timetable concerning its student population and the provincial or regional academic needs. It follows the strategy indicating the campuses seek to communicate three messages: 1 . they are earnestly committed to candidÇe's scholarly credentials; 2 . they are intellectually lively and well committed to diversity and excellence in the faculty, staff and student body; and 3. they follow to provide a place with a variety of humane, family-friendly policies. Therefore, an index has been defined to determine the existing shortage of faculty members. Such an index enables us to evaluate the state of the academic fields of study as well as the status of the academic requirements in different divisions and departments of a college. In effect, it is based on the amount of credits in terms of which tuition fee is ${ }^{\mathrm{p}}$ aid in each division.
\end{abstract}

Key words: faculty; credit; academic; scope; borders; requirements; recruit

\section{Introduction}

To achieve the highest academic standards, to fulfil its initially set goals, this university is decisive to take both high qualities of education and affirmative action programs in geographical distributions. More important than all is the principle of equal educational opportunity which is prime consideration of this university. Therefore, all efforts are made, in terms of social justice, by the experts and programmers to establish regional uniform policies and procedures that ensure a fair and open hiring practice and a work environment that is free from any forms of ignoring credential aspects. Affirmative action at this university is all based on a 
proactive commitment to engage in activities that will result in quality education and equity for all individuals to enjoy equal chance in developing their faculties.

The faculty recruitment process plays a vital role in helping the University meet these objectives by recruiting and retaining a wellqualified and diverse faculty in response to the above-stated goals. In effect, the strategic management abiding system at this university has enabled the search committees involved in faculty recruitment to have the power to make substantive changes to the academic environment. These efforts to recruit, retain, and promote diverse faculty in science and engineering have produced great recognitions. To be succinct, this university recognizes the importance to society of the creation of knowledge and its dissemination, as well as the learning and classroom experiences of its student and faculty community. All in all, the principles of commitment to scholarly credentials, fairness and equity play an integral role in all personnel decisions toward provision of diversity and excellence of faculty. Decisions are expected to be based upon an applicant's knowledge, abilities, and achievements as well as the individual's potential to contribute to the academic endeavours of the University. In fact, they evaluate candidates for academic positions on the basis of their scholarly credentials. The faculty recruitment guide is intended to provide the overall framework of policies and procedures to guide faculty committees, departments, Deans, and others in achieving the University's goal of managed change and the recruitment and retention of a well-qualified and diverse community of teacher-scholars. All appointments to tenure-line (both probationary and tenured) positions shall follow this process. Conducting a search in a timely and efficient manner is essential to the process of recruiting well-qualified faculty. Timing is critical if interviews and offers of employment are to be made in a competitive manner.

With regard to giving academic services to more than $1,300,000$ students in about 300 university branches and centers established throughout the country, the Islamic Azad University, IAU, as one of the greatest higher ed ucational centers of the country, has undertaken the responsibility of educating more than $60 \%$ of the total candidates admitted to various universities across the country. Internationally speaking, as the number of fulltime faculty members is regarded as one of the quality indices of an educational and research complex on the one hand, and the number of part-time instructors and lecturers not only brings about lack of consistency in curriculum development but it also makes no contribution to the investigational domain and it naturally sounds to be a negative index to research works, on the other. Consequently, the IAU tends to achieve a rational student fulltime faculty proportion index. This enterprise is being realized in terms of both the deliberately arranged timetable and the strategic schedules the IAU follows. Academically speaking, the IAU needs an index so as to determine the number of the required faculty members to supply the educational and research demands. 


\section{Process}

Those who apply for the vacancies address their vita and resumes and mail them to the Chair of the search committee, the Chair of the department, or the Chief of the division. Then the number of vita and resumes which have been received for a faculty position will be forwarded to the appropriate hiring authority. Prior to extending a formal offer to the successful candidate, the letter of offer will be reviewed and approved by the appropriate Dean, lett ers of offer to prospective Chairs will be reviewed and approved by the President. At the end of the recruitment process the faculty recruitment report along with the vita and resumes of all applicants for the position should be forwarded to the Dean's Office with the Faculty Appointment Packet to be surveyed. These procedures will establish a documented database necessary to ensure compliance with the equal employment policies of the university.

\section{Az Index}

Since faculty members form the substantial element of any university, it necessitates finding a mechanism as wjl as an index to represent university requirements for faculty members regarding the variety of fields of study. The more the number of credit hours to be given to hourly paid instructors, the more outstandingly the shortage of faculty members is felt. So such an index has been devised termed as Az index.

The Faculty Shortage Index

$($ Az Index $)=\mathrm{N} 1 / \mathrm{N} 2$

Notice: $\mathrm{N} 1=$ the Number of credit hours per semester

$\mathrm{N} 2=$ the Number of hours a tenured tract faculty has to teach

For example, if a university branch has got 765, 1275, and 2550 credit hours for such courses as organic chemistry, mineral chemistry and physics chemistry to be taught by hourly paid instructors, the Az index shows the number of faculty members required as 3,5 and 10, respectively. The index of faculty shortage would be as follows: 
Organic chemistry $\mathrm{N}=\mathrm{N} 1 / \mathrm{N} 2=765 / 255=3$

Mineral chemistry $\mathrm{N}=\mathrm{N} 1 / \mathrm{N} 2=1275 / 255=5$

Physics chemistry N=N1/N2=2550/255

Notice: N2 $=255$ which indicates the number of obligatory credit hours taught by a tenure tract Ph.D. holder. Moreover, if the instructor is an MA/MS holder, N2 would be equal to 277 credit hours. In addition To determine a succinctly definable yardstick for the recruitment of the faculty members, it seems necessary to have an index representing the demands the university branches do have in terms of the number and variety of their academic specializations. It goes without saying that the more credit hours to be taught by part-time lecturers at a university branch, the more considerable and outstanding is the faculty vacancies at that particular branch. Hence, using the ratio of the credit hours taught by part time lecturers in each academic field in each semester represented as N1 to obligatory credits taught in each semester by fulltime faculty members represented as N2, one can achieve the Az index stated above. It is, in effect, an index which enables us to decide on the exact number of faculty vacancies in terms of each separate field and course. Considering the present statistical status of faculties and students, one can produce a proportion which may allow us to access the internationally valid academic standards. This index can be applied to the need analysis regarding Islamic Azad University faculty status to consider:

1) The present status of faculties available concerning the following considerations:

A. University branch

B. Educational groups at each college

C. Academic fields of study

D. Academic subfields of study

2) The ratio of faculty vacancies to students concerning the following considerations:

A. University branch

B. Educational groups at each college 
C. Academic fields of study

D. Academic subfields of study

Based on the carried-out surveys and the standardization of the demands pertinent to each subfield relevant to any field at each university branch, the faculty vacancies can be exactly estimated as a reliable and valid index. As a result, it necessitates presenting a mechanism and an index representing the demands on the part of each university branch in terms of the number and variety of the required specializations. Furthermore, it can be succinctly claimed that there is a direct relationship between the two parameters: the number of credits taught by the part- time teachers (N1) and the rate of faculty vacancy. This ratio can be formulized as the proportion of N1-as it was explained previously- to N2- the number of obligatory credits a full-time faculty has the duty to do- per semester.

\section{The Method of Calculating the Index of Faculty Vacancy Rate To}

determine the $\mathrm{Az}$ index, two parameters are taken into account:

1. The number of the credits in each academic field and subfield of study scheduled for the unemployed part-time or contract-based lecturers

2. The number of the credits the fulltime faculty members are obliged to undertake as their task (272 hours for lecturers and 255 hours for associate ${ }^{\mathrm{p}}$ rofessors) ${ }^{\mathrm{p}}$ er semester

Az Index: shows a typical example of general specifications of a given university.

\begin{tabular}{|c|l|l|c|c|c|l|l|}
\hline $\begin{array}{l}\text { Name of } \begin{array}{l}\text { University } \\
\text { Branch }\end{array} \\
\text { Rank }\end{array}$ & Branch & Students No & \multicolumn{2}{|c|}{$\begin{array}{l}\text { Proportion of } \\
\text { Faculties to } \\
\text { Students }\end{array}$} & $\begin{array}{l}\text { N1: Total No. } \\
\text { of credits given } \\
\text { to part-time } \\
\text { teachers }\end{array}$ & $\begin{array}{l}\text { N2: No. of } \\
\text { obligatory credits } \\
\text { given to tenure } \\
\text { track faculties }\end{array}$ \\
\hline X & Very big & 13000 & Now & $\begin{array}{l}1-y r \\
\text { goal }\end{array}$ & $\begin{array}{l}2-y r \\
\text { goal }\end{array}$ & & \\
\cline { 3 - 5 } & & & $1 / 50$ & $1 / 35$ & $1 / 30$ & \\
\hline
\end{tabular}

Table 1 specifies a given example of a branch of Islamic Azad University with its rank position in terms of a four point rank scale of "small, big, very big, and comprehensive" as well as the proportion of the existing number of faculties. Moreover, this proportion has been estimated not only through the present status but it has also been estimated based on one-year goals and two-year goals set by the given university branch. In fact, Az index has been defined in terms of the total number of credits assigned to part time teachers characterized as $\mathrm{N} 1$, and the number of credits assigned as obligation performed by a tenure track faculty member. 


\section{Az 1 Index: shows the statistics relevant to the existing faculty and the required number of tenure track faculties.}

\begin{tabular}{|l|l|l|c|c|c|c|c|c|c|}
\hline \multicolumn{4}{|c|}{ No. of Required Faculties } & \multicolumn{6}{c|}{ The existing number of faculties } \\
\hline No. & Field & Sub-field & N1 & $\begin{array}{c}\text { Az= } \\
\text { N1 } \\
\text { N2 }\end{array}$ & $\begin{array}{l}\text { MA/MS } \\
\text { holders }\end{array}$ & $\begin{array}{c}\text { MA/MS } \\
\text { Scholarships } \\
\text { granted }\end{array}$ & $\begin{array}{c}\text { Ph.D. } \\
\text { Scholarships } \\
\text { granted }\end{array}$ & $\begin{array}{c}\text { MA/MS } \\
\text { holders }\end{array}$ & $\begin{array}{l}\text { Ph.D. } \\
\text { holders }\end{array}$ \\
\hline 1 & $\begin{array}{l}\text { Computer } \\
\text { Engineering }\end{array}$ & Hardware & 472 & 2 & 2 & - & 12 & 6 & 4 \\
\hline 2 & $\begin{array}{l}\text { Computer } \\
\text { Engineering }\end{array}$ & Software & 765 & 3 & 4 & - & 11 & 5 & 3 \\
\hline 3 & $\begin{array}{l}\text { Computer } \\
\text { Engineering }\end{array}$ & $\begin{array}{l}\text { Artificial } \\
\text { Intelligence }\end{array}$ & 255 & 1 & 1 & 2 & 5 & 3 & 3 \\
\hline
\end{tabular}

Total number of credits taught by part time lecturers $=1492$

$\sum \mathrm{AZ}=6$

Az 1 shows a general account of both the present status of the university branch in terms of the number of the existing and the required faculty members according to their academic degree, field, subfield, full ti number of credit hours assi ${ }^{\mathrm{g}}$ ned to ${ }^{\mathrm{p}}$ art time teachers.

To estimate the required number of the faculty members regarding the fields and the subfields needed th rou ${ }^{\mathrm{g}}$ hout the $6^{\text {th }} \mathrm{re}^{\mathrm{g}}$ ional branches of the Islamic Azad Universit ${ }^{\mathrm{y}}$, you can refer to the following typical example of the regional requirements shown in Az 2 Index. In effect, it is through the Az 2 index that both quantitative as well as qualitative developments can be achieved. Of course, the distribution of the recruitment number may help regional development as well. Consequently, by appropriate planning those in charge can do their jobs precisely.

Az 2 Index: Faculty Shortage in the $6^{\text {th }}$ Regional Branches of the Islamic Azad University 


\begin{tabular}{|c|c|c|c|c|c|c|c|c|c|c|c|c|c|c|c|c|c|c|c|}
\hline Field & $\begin{array}{l}\text { Needed } \\
\text { Subfield }\end{array}$ & & & & & & & & & & & & & & & & & & \\
\hline Com.E. & H.W. & 1 & 1 & 15 & 0 & 1 & 2 & 2 & 0 & 18 & 2 & 0 & 1 & 13 & 2 & 1 & 4 & 0 & 63 \\
\hline Com.E. & S.W. & 1 & 8 & 2 & 10 & 10 & 1 & 3 & 0 & 35 & 3 & 0 & 4 & 14 & 0 & 15 & 4 & 0 & 110 \\
\hline Com.E. & A.I. & 5 & 0 & 0 & 0 & 1 & 0 & 3 & 0 & 0 & 0 & 0 & 0 & 0 & 0 & 0 & 0 & 0 & 9 \\
\hline \multicolumn{2}{|c|}{ Total in C.E. group } & 7 & 9 & 17 & 10 & 12 & 3 & 8 & 0 & 53 & 5 & 0 & 5 & 27 & 2 & 16 & 8 & 0 & 182 \\
\hline E.E. & Elec. & 12 & 2 & 15 & 1 & 2 & 0 & 1 & 0 & 0 & 2 & 0 & 2 & 13 & 0 & 9 & 2 & 0 & 61 \\
\hline E.E. & Power & 0 & 2 & 2 & 2 & 2 & 0 & 2 & 0 & 42 & 2 & 0 & 4 & 25 & 0 & 6 & 3 & 0 & 92 \\
\hline E.E. & Tel.Com. & 8 & 1 & 0 & 0 & 2 & 0 & 0 & 0 & 1 & 2 & 01 & & 8 & 0 & 3 & 1 & 0 & 27 \\
\hline E.E. & Cont. & 0 & 1 & 0 & 1 & 0 & 0 & 0 & 0 & 1 & 2 & 0 & 1 & 0 & 0 & 1 & 0 & 0 & 7 \\
\hline E.E. & M.E. & 0 & 0 & 0 & 0 & 0 & 0 & 0 & 0 & 6 & 0 & 0 & 0 & 0 & 0 & 0 & 0 & 0 & 6 \\
\hline \multicolumn{2}{|c|}{ Total in E.E group } & 20 & 6 & 17 & 4 & 6 & 0 & 3 & 0 & 50 & 8 & 0 & 8 & 46 & 0 & 19 & 6 & 0 & 193 \\
\hline A.E. & Architec. & 1 & 2 & 4 & 16 & 0 & 0 & 2 & 0 & 39 & 0 & & 0 & 28 & 0 & 5 & 1 & 0 & 98 \\
\hline A.E. & Buil.Tec. & 1 & 1 & 2 & 0 & 0 & 0 & & 0 & 0 & 0 & 00 & & 0 & 0 & 0 & 1 & 0 & 5 \\
\hline A.E. & Civ.Des. & 1 & 1 & 1 & 0 & 0 & 0 & 0 & 0 & 0 & 0 & 0 & 0 & 0 & 0 & 0 & 1 & 0 & 4 \\
\hline A.E. & Civ.Plan. & 1 & 1 & 2 & 0 & 0 & & 00 & & 0 & 0 & 0 & 0 & 0 & 0 & 0 & 1 & 0 & 5 \\
\hline A.E. & Mon.Rec. & 0 & 0 & 0 & 0 & 0 & 00 & & 0 & 0 & 00 & & 0 & 0 & 0 & 0 & 0 & 0 & 0 \\
\hline A.E. & Energy & 1 & 0 & 0 & 0 & 0 & & 00 & & 0 & & 00 & & 0 & 0 & 0 & 0 & 0 & 1 \\
\hline \multicolumn{2}{|c|}{ Total in A.E. group } & 5 & 5 & 9 & 16 & 0 & & & 0203 & & & 0 & 0 & 28 & 0 & 5 & 4 & 0 & 113 \\
\hline N.R.E. & Env.Sc. & 0 & 0 & 0 & 1 & 0 & & 0 & 0 & 0 & 0 & 0 & 0 & 0 & 0 & 0 & 0 & 0 & 1 \\
\hline N.R.E. & Env.Ev. & 0 & 0 & 0 & 0 & 0 & 0 & 0 & 0 & 0 & 0 & 0 & 0 & 0 & 0 & 0 & 0 & 0 & 0 \\
\hline N.R.E. & W. Ind. & 0 & 0 & 0 & 0 & 0 & 0 & 0 & 0 & 0 & 0 & 0 & 0 & 0 & 0 & 0 & 0 & 0 & 0 \\
\hline N.R.E. & Foresting & 0 & 0 & 0 & 0 & 0 & & 00 & & 0 & 0 & 0 & 0 & 0 & 0 & 0 & 0 & 0 & 0 \\
\hline N.R.E. & $\begin{array}{l}\text { R.L.\& } \\
\text { W.S.M. }\end{array}$ & 0 & 0 & 0 & 0 & 0 & 0 & \begin{tabular}{|l|l|}
0 \\
\end{tabular} & 0 & 0 & \begin{tabular}{|l|}
0 \\
\end{tabular} & 0 & 0 & 0 & 0 & 0 & 0 & 0 & 0 \\
\hline
\end{tabular}

The full form of the abbreviations is as follows:

Com.E. $/$ C.E. $=$ Computer Engineering

H.W. $=$ Hard Ware

S.W. =Soft Ware

A.I. $=$ Artificial Intelligence

E.E. $=$ Electronics Engineering

Tel.Com. $=$ Telecommunication

Cont. $=$ Control

A.E. $=$ Architecture Engineering

Architect. $=$ Architecture

Buil. Tec. $=$ Buildiong Technology

Civ.Des. $=$ Civil Design

Mon. Rec. $=$ Monuments Reconstruction

N.R.E. = Natural Resources Engineering

Env. Sc. $=$ Environmental Science

Env.Ev. $=$ Environmental Evaluation 
W.Ind. = Wood Industry

R.L.\&W.S.M. = Range and Water Shed Management

\section{Discussion and Conclusions}

Taking what was developed into consideration, one can readily draw the conclusions that the $\mathrm{Az}$ index enables curricular developers to do the followings:

1. To specify the cone of academic faculty members in terms of academic ranks

2. To determine the faculty statistic of each group

3. To decide on the number of the faculty members in each subfield of study

4. To clarify the state of each field and to use the pertinent information for awarding scholarship to the faculty members

5. To formalize and confirm colleges in terms of their existing number of 6 .

To establish new

faculties as well as their faculty' s academic ranks

academic courses and

fields $u \sin ^{\mathrm{g}}$ the existin ${ }^{\mathrm{g}}$ facult ${ }^{\mathrm{y}}$

teams

7. To specify the faculty-student ratio in each university branch separately in terms of college, group, cours subfield

8. To specify the faculty deficiency required for the establishment of new courses and colleges

9. To decide on the proportion of associate professors to lecturers

10. To orient higher educational research activities for provision of the required faculty training

11. To embark on the improvement of the faculty-student ratio relationship in accordance with specific timetable and in terms of the faculty recruitment requirements of the pertinent Islamic Azad University branches using the index of faculty deficiency in proportion to faculty recruitment

\section{ROLES IN CONDUCTING A SEARCH FOR TENURE-LINE FACULTY}

A. Role of the Department Faculty 
To achieve the above-stated goals, the system has designated the followings:

The Department faculty members are responsible for establishing the position(s) in terms of their needs in terms of current number of tenured and probationary faculty in the department and number of lecturers hired in at least the past academic year or in a word in terms of the credits and the corresponding hours left without instructors.

The Department Chair is responsible for making a request to their highrank authorities then to the regional secretariats to conduct a search for the tenure-line position(s) in accordance with the criteria established by the faculty members of the department.

Departments are advised to have their packages completed at least six months before the anticipated date by which the search committee will choose the finalists to allow sufficient time for a successful search.

B. Role of the Dean 
The Dean is responsible for the quality and performance of the faculty in the college/school to ensure excellent quality academic instruction and excellence in research and other professional development activities of the faculty. To achieve these goals, the Dean has the responsibility for oversight of the search process, including budgetary decisions related to searches and hires. The Dean is responsible for ensuring that faculty search committees comply with University policies and adhere to the University's affirmative action guide

In effect, the central educational assi stant located in Tehran is in charge of what is termed as the diversity officer or designee in some European universities to provide an ongoing review of the search process to promote equal employment opportunity for diverse pool of qualified candidates and adherence to sound human resource practices, or to participate in the recruitment process from its initial stages to completion, and to inform the search committee of affirmative action practices and procedures necessary to ensure equal employment opportunity, including considerations regarding valid selection procedures and appropriate interview techniques. 


\section{ESTABLISHING THE POSITION}

A. Memo requesting opening of recruitment

A description of the requested position(s) must be approved by the majority vote of the tenured and probationary faculty. To ensure this concurrence of the department faculty, a majority of the faculty shall approve a memo stating the position including sub-discipline, qualifications, and expected rank. The transmittal of this memo from the Department Chair to the Dean will formalize the request for a search. A copy of the memo shall also be transmitted to the regional secretariat in 
provincial capital then if confirmed transferred to central office in Tehran. This memo shall include:

- Position justification (why needed, whether it is a new or replacement position, how it fits the department's short and long-term goals, etc.).

- Request for recruitment funds (publicity, travel, release time, etc.).

- Summary of consultation with faculty.

- Current number of tenured and probationary faculty in the department and number of lecturers (FTEF) hired in at least the past academic year.

\section{PREPARATION FOR THE SEARCH}

A. A search committee who are members with different perspectives and expertise and with a demonstrated commitment to diversity and excellence of the faculty consisting of probationary and tenured faculty is elected by the majority vote of the probationary and tenured department faculty. All department faculty members shall have the opportunity to nominate candidates for the search committee. The search committee shall consist of five but in critical conditions of a minimum of three members. It should be added that the search committee members are not necessarily belong to the same department but some are often outside the de

B. Search Committee Composition and Duties: Th e search committee should have appropriate representation for the sub-discipline or specialty in which an appointment is being sought. The department shall make a good faith effort to include faculty from undj-represented groups in the search committee. If there are not enough tenured and probationary faculty members from under-represented groups within the department, the department faculty may elect members from related disciplines.

Although the above-stated committee may approve a candidate, there is a morally oriented committee who are in charge of investigating around the candidate's moral, political and social face. Then the report will be sent to the central office in Tehran to be documented in his or her file.

While it is customary that recruitment packages are completed prior to advertising positions, the timing of advertising tenure-line positions may require that ads be developed and placed before the recruitment packages are completed. Ads and position descriptions must be approved by the special screening committee in Tehran.

\section{THE SEARCH PROCESS}

The search committee makes efforts to recruit a large and diverse pool of applicants. All prepared announcements and other publicity materials are 
sent out. Information is sent to all resources, contacts and publications. The search committee chair is responsible for responding to inquiries and correspondence in a timely manner.

Until the pool is approved, the search committee shall not evaluate the pool as a whole. However, individual committee members may review and evaluate the applications as soon as they are complete.

Everyone having access to the candidates' application files must keep such information confidential. Some applicants will want their candidacy to remain confidential until they become finalists. When an applicant requests this, his/her wishes must be respected. The search process is as follows:

B. Applicant Tracking System: As search committee receives applications, it must follow the established ATS (Applicant Tracking System) to document various search activities.

The findings of the present study indicate that the present situation requires us to have a leading regional planning council to require all academic educational facility planning process to adopt educational facilities plans and to enter into an regional agreementÇ and requiring that university boards identify information they will use to determine whether each university branch has found itself available capacity to accommodate new development.

So these planner have to develop a fiscal-impact-analysis model for evaluating the cost of infrastructure to support development. The development of the regional impact program is modified to clarify substantial deviation standards and to remove the acreage threshold for cejain types of developm ent; make an annual reporting requirement biennial. In effect, ther e must $b$ e minimum criteria requiring that the elements of the plan be consistent with each other and with the state comprehensive plan and the regional policy plan; that the elements include policies to guide future decisions and programs to ensure the plans would be implemented; that the elements include processes for interregional coordination; and that the elements identify procedures for evaluating the implementation of the plan. After a comprehensive plan has been adopted, subsequent changes are made through amendments to the plans.

References 
Katznelson, I. (2006). When Affirmative Action Was White. Poverty and Race Research Action Council 15(2).

Sommers, S. (2006). On Racial Diversity and Group Decision Making: Identifying Multiple Effects of Racial Composition on Jury Deliberations. Journal of Personality and Social Psychology 90 (4), 597-612.

A Study on the Status of Women Faculty in Science at MIT. (1999). The MIT FacultyNewsletter, Vol. XI, No. 4.

Mannix, Margaret, "Facing the Problem" PRISM, October 2002, pg 18-24 with email response: Death by a Thousand Cuts - Ainissa G. Ramirez, Ph.D.,

$\underline{\text { Scienceworks, }}$

Smith, Daryl G. How to Diversity the Faculty Academe. Sept-Oct. 2000. v. 86. No. 5 .

Trower, Cathy A. and Richard P. Chait. Faculty Diversity: Too little for too long, Harvard Magazine, March-April 2002.

American Educational Research Association - Special Interest Groups 1) Research on Women and Education, 2) Research on Black Americans, 3) Research on the Education of Asian \& Pacific Americans, 4) Hispanic Research Issues, 5) Critical Examination of Race, Ethnicity, Class, \& Gendeïin Education (http://www.aera.net)

American Physical Society - Committee on the Status of Women in Physics, Committee on Minorities in Physics (http://www.aps.org/)

American Political Science Association - Sections on Women \& Politics, and Race, Ethn icity \& Politics (http://www.apsanet.org/ rep/)

Society of Women Engineers (http://www.swe.org)

Society of Hispanic Professional Engineers (http://www.shpe.org)

American Indian Science \& Engineering Society (http://www.aises.org)

National Society of Black Engineers (http://www.nsbe.org)

http://www.cic.uiuc.edu/programs/DirectoryOfWomenInScienceAndEngin eering/

http://www.cic.uiuc.edu/programs/DirectoryOfMinorityCandidates/

http://www.case.edu/president/aaction/Faculty\%20Search\%20Guide.pdf

The guidance to Faculty Recruitment Committee in the $6^{\text {th }}$ Regional Secretariat of Islamic Azad University in Khuzestan Province, Iran 